\title{
Traditional African Religion in Natural Resources Conservation and Management in Cross River State, Nigeria
}

\author{
Eneji C. V. O. ${ }^{1}$, Ntamu G. U. ${ }^{2}$, Unwanade C. C. ${ }^{3}$, Godwin A. B ${ }^{4}$, Bassey J. E. ${ }^{4}$, Willaims J. ${ }^{1}$ \& Joseph Ignatius ${ }^{1}$ \\ ${ }^{1}$ Department of Geography, (Rural Development), Federal University of Technology, Yola, Nigeria \\ ${ }^{2}$ Department of Religious and Cultural Studies, University of Calabar, Nigeria \\ ${ }^{3}$ Department of Sociology, University of Calabar, Nigeria \\ ${ }^{4}$ Department of Adult and Continuing Education, University of Calabar, Nigeria \\ Correspondence: Eneji C. V. O., Department of Geography, (Rural Development), Federal University of \\ Technology, Yola, Nigeria. Tel: 234-816-488-4244. E-mail: vcogareneji@yahoo.com
}

Received: June 25, 2012 Accepted: August 27, 2012 Online Published: October 16, 2012

doi:10.5539/enrr.v2n4p45 URL: http://dx.doi.org/10.5539/enrr.v2n4p45

\begin{abstract}
This article assessed the roles Traditional African Religion can play in the conservation and management of natural resources especially forest resources in Cross River State Nigeria. Some religious practices in the African Traditional Religion like methods worship, initiation rites, and the invocation of the sacred powers of the supreme beings, how these gods communicate their will to humans through the chief priests and how the gods are atoned if provoked were examined. The stronghold of African religion rests wholly on the ascription of psychic powers to any part of the natural environment as the abodes of the gods and goddesses of the land and the protection of these abodes of the gods/goddesses. The protection of the abodes of the gods from entrance, utilization and exploitation overtly or covertly encourages conservation and management of natural resources. Forbidden areas associated with worship contribute to natural resources conservation and management in Cross River State. These African traditional religious strategies for natural resource conservation and management have somehow been eroded by acculturation and enculturation of most African communities through the introduction of Christianity as a modern way of worship. The use of literature review and personal interviews was adopted by the authors for the study. The authors recommended a re-visitation of the principles of traditional African religious practices where modern conservation programs could integrate traditional knowledge systems into their activities in the conservation and management of our natural resources.
\end{abstract}

Keyword: traditional African religion, natural resource conservation, sacred grove, evil forest, christianity, evil forest

\section{Introduction}

Local people have developed a variety of consistent resource conservation and management strategies in tropical Africa, Asia, and South America in the past (Appiah-Opoku, 2007). Traditional African societies also observed environmental ethics that help in regulating their interactions with the natural environment (Shastri et al., 2002). For instance, it is observed that African traditional religion (ATR) is a religion with environmental characteristics, features and symbolism; but the proponents and propagators of Christianity saw the ATR's belief systems, worship and practices as rather inimical to the growth, unity, peace and cohesion of our communities, whereas, this is exactly what the ATR stands for in every society or community (Appiah-Opoku, 2007). The introduction of western religion and formal education somehow eroded the rich cultural values and religious diversities of Africans and also changed their belief and worship systems (Smith \& Wishnie, 2000).

It has been acknowledge in the findings of Eneji et al. (2009a) that deforestation and land use is a major problem facing Nigeria and indeed Cross River state. This is as a result of the activities of rural farmers and multinationals on traditionally protected areas in the forest zones as a result of increasing pressure from the demands of hard wood, agricultural land and forest products. It was further observed that indiscriminate land use including farming is a problem that forest within the state has to contend. While illegal logging of trees and harvesting of non timber forest products (NTFPs) continues to be a major problem in forest reserves, much has been done to reduce this trend. There is threat to Wildlife populations in all reserves from illegal hunting, grazing 
and the activities of local farmers. There is the wanton and indiscriminate exploitation and collection of other forest products, like bitter kola, (Garcinia kola), bush mango (Irvingia gabonensis), hot leaves, cane, camwood (Ptheracarpus soyauxii), kola nut, (Kola nitida or Kola accuminata) snails (Archachatina spp chewing sticks, poles and afang (Gnetum Africana), (Eneji et al., 2009a).

Changes in land use policy have taken control of land and other natural resources management from the hands of local authorities. This control gave the ancestral right and authority of caring, protecting and managing forest resources, land, water and other such resources located within such lands to the state. Corrupt elements of society have abused the main tenet of this land use act of 1979. Furthermore, the creation of forest reserves and the Cross River National Park to protect forest and forestland for future generations has also removed control from traditional authorities leaving less forests land for the ever growing population. This is also noticed on the pressure put on natural resources by the growing population in terms of housing human population, clothing and feeding them and providing an aesthetic environment for the populace. The forest is particularly very important to African; this is so in terms of both tangible and non tangible benefits derived there from. These benefits include timber, rattan, cane wood, resin, gum, mat, rope and other non timber forest products like afang, bush mango, bitter kola, hot leaf, otasi, (afro mumu), mushroom, spices among others. Non tangible benefits include environmental services like local climate modification, carbon sink, wind breakers, nutrient recycling, and watershed protection among others. Outside the above benefits, forest products and wild animals also provide valuable sources of income, household tools and some therapeutic medicine (Falconer, 1992; Wilson, 1998).

If this is the case, why then do people continue to destroy forests and overexploit forest resources that are so vital to their own survival and still remain antagonistic to a system that seeks to conserve those resources? Based on the services provided by the forest for both human and other living things, it has long been recognized that the abundance and existence of these forest resources are under serious threats from human activities. Many management techniques have already been adopted to conserve and manage these forests, but the results so far seem to be at best a mirage.

Traditional African Religion (ATR) has latently been discovered to be one of such efforts geared towards the preservation of both forest and other natural resources. ATR has inherent environmental resource conservation and management principles, why is this religion not promoted by conservation experts for the conservation and management of these resources? Which specifically are those aspects of the religion that can be adopted or promoted for the management and conservation of our natural resources? It is on this premise that the authors $\mathrm{x}$-rayed the role of traditional African religion in the conservation and management of forest and other natural resources in Cross River State, Nigeria. The objectives of the study therefore are to:

a) Assess examine some traditional African religion as practiced in some part of Cross River State, Nigeria.

b) Examine the roles of ATR in natural resources conservation in Cross River State, Nigeria.

c) To recommend/suggest some aspect of traditional African Religion in natural resources management.

\subsection{Origin of African Traditional Religion}

The word religion is derived from a Latin word religio, which means both earnest observance of ritual obligations and an inward spirit of reverence (Paden, 2009). In modern usage, religion has an ambiguous meaning that reflects the enormous variety of ways the term can be interpreted. At one extreme, many committed believers recognize only their own tradition as a religion, understanding expressions such as worship and prayer to refer exclusively to the practices of their tradition (Paden, 2009). By defining religion as a sacred engagement with what is taken to be a spiritual reality, religion is not an object with a single, fixed meaning, or even a zone with clear boundaries. It is an aspect of human experience that may intersect, incorporate, or transcend other aspects of life and society. Such a definition avoids the drawbacks of limiting the investigation of religion to Western or biblical categories such as monotheism (belief in one god only) or to church structure, which are not universal.

In Buddhism, gods are not as central as the idea of a Buddha (fully enlightened human being). In many traditional cultures the idea of a sacred cosmic order is the most prominent religious belief. Because of this variety, some scholars prefer to use a general term such as the sacred to designate the common foundation of religious life. In all cultures, human beings make a practice of interacting with what is taken to be spiritual powers. These powers may be in the form of gods, spirits, ancestors, or any kind of sacred reality with which humans believe themselves to be connected. Sometimes a spiritual power is understood broadly as an all-embracing reality, and sometimes it is approached through its manifestation in special symbols. It may be regarded as external to the self, internal, or both. People interact with such a presence in a sacred manner-that is, with reverence and care. 
Religion is the term most commonly used to designate this complex and diverse realm of human experience (Paden, 2009).

Just as Africans have grown over the ages, so also is the Africa Traditional Religion. ATR began as a set of code of conducts and ethics guiding the activities of man in his society. In an attempt to enforce the precepts of this new ethics and code of conduct, the community members charged with the enforcement of these rules, code and ethical behavior formed themselves into an association, where their rules, code of conduct and membership was widely jealoused and accepted. As time progresses, communicating with the ancestors to guide human existence became expedient, so a chief priest is always elected by a serving priest who teaches the convert the way of the gods and also how to make incantations and appease the gods, so this new apprentice takes over the duty of divination in the event that the chief priest is no more or he is seriously ill. This trend progressed to a cult or a sacred group since one person may not force the entire community to obey all rules, so membership was now open to the public. Recruiting of members became open. Those who became committed to this new order form themselves and began making sacrifices to these gods they hold sacred; this was how the African Traditional religion came about.

Traditional African religion (ATR) as done in most part of African communities are environmentally friendly and sustainable, thus contributing so much to natural resources sustainability and conservation. In Africa and indeed Nigeria, the traditional religion holds the strength on the ascription of psychic/supernatural powers to objects called gods and goddesses. The major tenet of African traditional religion and belief system lies in the belief that the abode of the gods and goddesses can be within the community. The community gods may decide to have their abodes on rock, streams, pond, tress, land or anywhere they so desire. The gods choose their followers through the rites of initiation with a core messenger who is the mouth piece of the gods living among human beings. The gods or goddess communicate their will to the people through the juju priest or chief priest. This belief system states that the gods protect the community members from harm, famine, bareness, impotence, drought, epidemics, and war among others. The gods avenge their anger on whoever omits or commits any flaw for which their presence forbids, hence, the cultural system holds all the precepts of the laws of the gods to a very high esteem (Shastri, et al., 2002; Tupper, 2002; Udgaonkar, 2002; Utkarsh et al., 1999; International Institute for Environment and Development, 1992). Western religious conversion, cultural orientation and acculturation have impacted very negatively on society in the course of man's existence. Because the Christianity has consistently seen nothing good in ATR, hence it has forced its adherents to see nothing good in ATR as such the belief system, practice, worship, reverence and ascription of psychic powers to the gods have been completely rendered impotent by the teachings of the Christian religion.

From the very first page of The Bible, Genesis 1: 26, in the story of creation God gave man an order, so fiat an authority to rule over the whole world. God gave man the authority to subdue the earth, all the creatures of earth and all it resources. Wilson (1998) observed that by implication this word dominion has both domination and stewardship apparatus. From the domination perspective, humans are said to have domination over the natural environment in ways that empowers us to treat nature the way it pleases us. This perspective sees natural environment as having been merely instrumental or having extrinsic value and provides justification for humanity's exploitation of natural resources. This is premised on the fact that it is our right as superior creatures, heir apparent and controlling God's creation on earth. This is the beginning of our environmental woes and conflict (McCammon, 2003; Henshey, 2011; Singh, 2002). In most parts of Africa, things like sacred groves found in Ghana and other West African countries are very practical systems of indigenous strategies for the management and conservation of our natural environment within the rural communities. In his research on traditional and indigenous methods of conserving biodiversity, Environmental Protection Council, (1976) identified four indigenous methods for conserving biodiversity in Ghana and other West African sub region, (Nigeria inclusive), these methods include:

- $\quad$ Religious traditions: temple forests, monastery forests, sanctified and deitified trees.

- $\quad$ Traditional tribal traditions: sacred forests, sacred groves and sacred trees.

- $\quad$ Royal traditions: royal hunting preserves, elephant forests, royal gardens etc.

- Livelihood traditions: forests and groves serving as cultural and social space and source of livelihood products and services (Simberloff \& Abele, 1976; Silori \& Badola, 2000).

In traditional African Religion, both men and women represent the gods and goddesses, but most often, it is the men that are initiated into these community cults or sects which are often enshrined in religious or cultural beliefs and superstitions and enforced by taboos. The taboos and beliefs have legal backing in the rules and institutions of the communities which are strong enough in the past to make people obey the religious and cultural regulations (Venkataraman, 2000; Cox, 1995; Cox, 2000; Smith \& Wishnie, 2000). 
Confirming the position of the Holy Qur'an on conservation, some key chapters and verses supports the conservation of natural resources: Fitrah, Mizan and Tauhid, Khalifah, these portions identified specifically the role of man in resources conservation. In Sumatra, some management policies support the introduction of religious doctrines into land management policies, these areas are Al-Mawat, land regeneration plan, Harim for water resource protection, Himoar for sustainable resources management (Deb \& Malhotra, 2001; Henshey, 2011; Johnson et al., 2001).

For Africans there is no clear separation between what is secular and what is sacred. Everything and every act are looked upon in a religious and customary perspective. Africans view themselves as part of the environment (Mkenda, 2010; Taylor, 2002). Man is conceivable only in this cosmic interweavement. This web of relationship is what makes Africans view the earth as their mother and themselves as her children. Little wonder, Africans refer to their land as mother earth. Despite the fact that humanity, nature and the gods are distinct concepts, they belong to some ontological categories that are interrelated and interdependent. Therefore plants, animals, rock, water and other non-living things are part of nature, which is the product of creation deserving to be respected as much as human beings who are also part of nature. This is what makes Africans regard themselves as being in close relationship with the entire cosmos (Taylor, 2002). This position of man being a constituent part of the environment and God's creation, it is expedient that man must protect the interest of other part of God's creations, this was confirmed by Mkenda (2010) and Snoo and Bertels (2001).

Henshey (2011) posited that in traditional African societies like Nigeria, Ghana, and many others, many people believed that rocks, trees streams, ponds and forests were the manifestation of the power of the Supreme Being. He saw these things as ideal places to meet their supreme being or the gods. Cox (1995) holds that in traditional African societies there are many shrines, and these shrines were associated with big trees such as mimosop, fig trees and baobabs, iroko, mahogany among others. This forced Deb, et al. (1997) to conclude that these trees together with the vegetation around were preserved as sacred places for worship. Africans did not just attach much importance to trees and herbs just for spiritual purposes, but also because trees, herbs and plants in general were useful in enhancing human life. Tree leaves, bark, roots and grasses provided herbal medicines to human beings and to wild and domestic animals; trees were also seen as being symbols of god's presence among people, (Tilman, 2000). Thompson and Homewood (2002) also found out that rocks, ponds, lands, streams and other part of the environment were also the abodes of the gods, so shrines, sanctuaries, temples and sacred groves were all meant for the worship, consultation and appeasements of the gods. This was also supported by the findings of Eneji et al. (2009b), Paden (2009), Appiah-Opoku (2007) and Kimmerer (2002).

\subsection{Some Belief System in Cross River State}

In almost every traditional African setting or community, each community has what they revere or hold sacred either as the presence of their gods or their goddesses, or there is a very important symbolic reason attached to such objects in the course of their existence. In almost every community in Cross River, there is hardly any community that exists without a sacred groove, evil forest, sacred pond, evil stream, or forbidden forest. Where some part of the environment is delineated for the worship of the gods (Eneji et al., 2009a; Tiwari et al., 1998).

In Bekwarra, (Gakem) of Cross River state, the road runner (anyiribom) is not killed. Ancient legendry has it that during war, the bird follows the trail of Gakem people and wipes their footprint so that the enemies may be prevented from tracing their direction and attacking them. In Etung local government the god of "ogbogoro"; is believed to be the god of fruitfulness and the gift of children. When there is poor harvest in Ejaghamland, (Etung, and Akamkpa) the people make sacrifices to this god. When a woman after marriage cannot have children, the god of ogbogoro is appeased with a sacrifice, thereby making request for children from such gods. The Ogolobi pond located in Adihe village, Otukpuru ward, Bekwarra, is a mysterious pond harvested by the entire Bekwarra kingdom once every seven years. Mudfish is the only species of fish harvested and shared together by everybody present; any other species of fish caught during this day is owned by whoever catches it during the harvesting period. It is a taboo for anybody to go fishing in the pond on his own; it is completely forbidden and very detrimental to any trespasser. So entrant into the pond alone is frightening. Within the pond in question there is an iroko tree and a mahogany tree, these trees are well over seventy years. There is also a cobra well over thirty years and more than 3 meters long. These are believed to be mysterious (Eneji et al., 2009a; Eneji, et al., 2009b; International Institute for Environment and Development, 1992).

In Beten also in Bekwarra, there is another rock called 'Uka Ochiifu' the rock here is believed to be the tomb of those killed during the first Bekwarra intertribal war with the Tivs of Benue state. This rock also is believed to be the place where the Nigerian and Biafran soldiers killed during the civil war were buried; nobody does anything within the rock zone. In Bewo another community in Bekwarra, there is a forest and a stream where there is 
human hand print. Ancestral legend has it that when Odama Ashide had a problem with his brother, he migrated away from Obanliku and as they got to this small stream in Bekwarra, Odama being full of age had to put his hands on the rock by the shore of the stream to enable him cross the stream, his hand remained imprinted there till today. In this forest and the stream, fishing and other activities are not allowed within this place. In Etung, there is a sacred pond called salt lake (Ejagham Lake). Harvesting of fish here is strictly prohibited, but when fish leaves this lake to another stream, harvesting can be done there in the stream. There is also the traditional Ekpe cult in most Ejagham and Efik communities, while in Obudu the Ekwong traditional institutions guide the conduct of men in the community.

There is an evil forest at Iruan and Arangha all in Boki, these evil forests is where bad people in the community are sent to go and die. If you are a witch or a wizard and have caused havoc in the community, or one dies in an accident such as auto crash or from a tree or palm tree, such corpse are taken to this forest. Some of these evil forests are the burial ground for the royals of the community. In Biase, there is also a burial ground for slaves, nobody wants to be associated with slavery, so the area remain a very thick forest since it is believed that the last slave buried there was before the stopping of slave trade in Nigeria. In Alifokpa in Yache, in Yala local government area, there is also a sacred grove where the remains of the ancestral fathers of the Alifokpa people were buried hundreds of years ago, no farming, felling of trees or harvesting of vegetables is done here. There is also a pond in Yache in Yala LGA, which nobody goes near there, here crocodile, iguana and some wild sea animals are found here. If anybody strays to this pond, the person may be eaten by the wild beast, but the community believes that the person would be killed by the spirit. There are forests where children born like animals are thrown. This forest is also forbidden from entrance except on such occasions. In Bateriko, some part of the forest is strictly reserve as the home of the gods, here no entrance is allowed into this forest, even when crops are cultivated close to the area, it does not give any good yield.

\section{Methodology}

The method of data collection and fact used in this research is personal interview, literature review, group discussion, and site visitation. A total of 30 communities were purposefully selected and visited for the study. The researchers interviewed a total of three persons including the chief, women leader and chief priest of various community deities. Where the chief or women leaders of any community are too young to know the traditional/cultural practices of their communities, the researchers resorted to interview older members of the community. This happened in some communities like Bumaji, Arangha, Ukalom all in Boki LGA, and some communities like Otukpuru, Adihe, Akpakpa, Bewo all in Bekwarra LGA. The choice of purposeful selection is because these communities have established religious and cultural practices already which some literature and the tourism initiative of the Cross River State Government have little documentation, hence the need for purposeful selection of the thirty communities under study. The communities are located within the following local government areas: Ogoja, Etung, Boki, Bekwarra, Obudu, Obanliku, Yala, Akamkpa and Biase. Some traditional and cultural practices are similar, with the same name in some communities. The findings from the field were documented and their implication discussed with our interviewees in the various communities in Cross River State.

\section{Results of Findings from the Interview}

It was gathered from the interview conducted in the field that most traditional African practices were consistent with modern day conservation ethics. The ascription of supernatural and psychic powers to a portion of the environment and protecting such resources through taboos, laws and totemic believe helped in conserving and protecting the environment and its resources.

* The delineation of some part of the forest as sacred abode of the gods also encourages the conservation of forest resources including all the wildlife within such forest.

* The forbidding of fishing and collecting of any aquatic species from any body of water as abode of the gods also encourage the conservation and management of aquatic resources.

* The belief in the cleaning and clearing of water sources and the regulation that forbids the clearing, cultivation and construction of residential structures within certain distance away from water source is in modern terms known as watershed protection.

- The various community sect eg Ekpe group, Ekwom, Ogrinya, Atam etc are used as enforcement officers of the traditional value system, this is what has been replaced by forest guards, and rangers etc. their duty contributes to sustainable development and resources conservation. 
* Above all, citizen's participation was paramount as they were part and parcel of these resource management strategies in all the communities.

\section{Discussion of Findings}

From the interview so far done, it has been discovered that despite the wrong impression Christians have about ATR, this religious practices have a strong element elements of conservation techniques that can be borrowed for effective conservation of natural resources especially forest resources. This is so because the practice ascribe certain powers to some portion of the environment as the abodes of the gods, this place is strictly prohibited from entrant by anybody, here resources are left untouched and preserve in its natural state. Fromm the field, since the community members are used as enforcement officers to enforce the laws and impose sanctions on offenders, it means there is a participatory management activities where the community members are aware of the taboos and practice them on their own volition. Here there is community participation and the management of these resources was the collective action of one and every member of the communities. Here representation was at the highest level and community can at this point be held accountable for any mismanagement of all these resources within their communities. Duty bearers can also be held responsible for the management and conservation of natural resources. In another response why most African communities, Cross River inclusive revere their natural resources so much an elder gave this response

For traditional Africans, land and water are very precious gifts from God the Creator. The strong connection between Africans and land is seen not only as an economic resource, but also as a home, a place of sacrifice and offerings. If there is any struggle or fight for land among traditional African society or members, it is not simply for economic control but for socio-cultural, moral and religious motives. The African beliefs and taboos helped in enforcing rules and regulations for environmental preservation because people refrained from using resources carelessly, especially as it is related to sacred places.

On how they feel traditional religion help in the conservation of forest and other resources, another elder has this to say

When the Ogolobi pond was still being practice, you can catch a mud fish that I will struggle to lift up with both hands, but I assure you, go to the stream now and see if you can even catch a fish that you can hardly lift up with one hand. They now use gamalin 20 and dynamite to fish here, so they kill everything on site. This was what never happened during the Ogolobi era, because you might poison the river which will go down to the Ogolobi pond and kill fish there too and you are liable to pay for it.

In Etung, what happened that people now bush bushes and kill animals that were taboos before, the chief responded that

everybody now says they are Christians and that the ancestral belief was misleading, God gave man dominion over all living creatures for man's satisfaction of his needs, so why should anybody put restrictions on the use of any part f God's creation? We must exploit these resources to our satisfaction. God was not a fool because he knows we were going to need these resources.

These are all indications that Christianity has played a serious part in the erosion of former traditional belief systems. Things formerly held sacrosanct have been destroyed and the ascription of psychic powers to these objects of worship have been completely removed, hence traditional African religion is now seen as an evil thing to belief, but without considering the efficacy of the belief system in conservation and management of environmental resources. Most women in the communities visited complained of the effect of the farming system along watershed, where dry season farming is done for market gardening. This was one thing that was a taboo in the traditional system because people were restricted from cultivating or farming near any source of drinking water.

Look at this stream, it was a very deep stream, if you come here to fetch water alone and you are not careful, you may drown inside, but today because they have cut down all these trees, look out water is getting drier and drier, who knows, maybe one day, we may not have drinking water again in the community.

Community members were aware of the roles African Traditional Religion played in the conservation of forest resources, this was given a proper coverage by one Chief Charles Effiong in Oban and I quote his words

Christianity should be blamed for all the rubbish we are seeing today, Christianity without $m$ oral etiquette is bad, how will we live in harmony when the rights of members of any ecosystem is not respected? Humans kill animals anyhow, they do not feel for them, nobody sues anybody for abusing the rights of fellow animals, and environmental resources are used without respect. If if unfortunate that laws do not make meanings in Nigeria, if not, animals have their rights and someone can sue another for abusing the rights of animals, but it does not 
work in our country. Look at the way industries are cited without thinking about its effect on the community. If traditional religion is still practiced, most of these environmental problems would have been avoided.

From these discussion, so far, African traditional religion has a part to play in the conservation and management of environmental resources especially forest resources in cross river state and other part of the globe where it is practiced, hence the need to revive and resuscitate the religious practices in communities where there were once practiced. The findings from these interview and discussion s confirmed the findings of Gyamfi-Fenteng and Abbiw (1992), Dwomoh (1990) who observed that because of the strong belief and practice of ATR and the delineation of their places of worship in the form of shrines, temple and groves, several categories of these places of worships exist, many are small (less than one hectare), often housing object like trees, pond, stone, or rock ascribed as the abodes of the god (Dorm-Adzobu et al., 1991; Udgaonkar, 2002). Such small areas may be very significant in terms of biodiversity conservation and management. Traditionally, there are some species of both plants and animals within such place of worship. Such species were strictly protected. In some cases, even touching the species was forbidden. These religious practices and worship were latently encouraging conservation and management of forest and other natural resources, see (Fargey, 1991; Mkenda, 2010; Tunon \& Bruhn, 1994; Tupper, 2002; Udgaonkar, 2002; Utkarsh, et al., 1999).

\section{Conclusion}

Traditional religion and cultural practices have contributed in the conservation of resources through the ascription of psychic powers to both animate and inanimate objects like rock, stream, tree, forest land etc, these ascriptions of the supreme powers and the belief and respect for the gods of the land holds the string to reverence and respect for these objects. Belief in the existence of a supreme being responsible for the protection of the communities has enabled the traditional African communities to voluntarily take and participate in the management of natural resources seriously. With all these respects and reverence ascribed to the gods and their abodes, exclusion from entrance into their abode was the key concept to conservation, followed by the rules and sanctions put on offenders.

Man in modern times sees the environment as his rightful property where he decides how it should be used, whether the process of exploitation is sustainable or not. This is so because most environmental resources are common pool resources with no well defined property rights. In traditional days, for the purpose of natural resources conservation and management, community craft rules, designed policies and execute them to the benefit of the entire community, but this is not the case today. Like in most villages, people use Gamalin 20 and DDT for fishing. In time past, traditional priests and elders in the villages invoked indigenous beliefs in spirits of water bodies to declare this method of fishing a taboo. The indigenous beliefs and taboo contributed immensely and effectively to the reduction in the incidence of fishing with chemical in the area under study. There were rules to protect trees, streams and rivers as well as governing council who are charged with the responsibilities of managing natural resources. This s why Christianity is blamed for these moral laxity in resource management. A number of sacred groves have been destroyed as a result of Christianity infiltration and urban and infrastructural development into rural hinterlands, but many still survive. But today, things that were held sacrosanct as totem and taboo are now seen as every other thing with very minimal value attached or as relics of what once was. This forgoing of the ascription of psychic powers to some objects are practiced in ATR has lost its efficacy and usefulness, this is in confirmation of the findings of Appiah-Opoku (2005), which was previously discovered by Wilson (2002) and World Conservation Union, (1994). In conclusion, traditional African religion practices belief in nature, holds nature as a partner in this struggle for existence. The traditional African man sees man and nature as inseparable and closely knit together, hence the religious and cultural practices belief on the tenet of nature earthsmanship.

\section{Recommendation}

There should be a re-visitation of some of the traditional religious belief system and cultural practices that encourage the conservation of natural resources for sustainable development in Cross River State and Nigeria as a whole. Specifically this research suggests that these areas would be beneficial to the traditional African society, conservation experts, and the rural communities where these practices are carried out.

Religious leaders (pastors, priest, imams, chief priest etc) should preach and encourage more on the sections of the bible that sees man' existence as closely knit to the environment and the provision of other environmental services which man needs for his survival on earth.

Researchers, conservation experts and modern communities should pick those practices and systems that encourage conservation and management of natural resources. By so doing, the rural communities within whose domain these resources are located would willingly and voluntarily participate in the management and 
conservation of the natural resources within their communities and also benefit from such management activities. Communities should be engaged in the management of their community resources, this can be done through community based natural resource management approach.

There should equal involvement of all facets of the community in matters that affects the community resources management. Here the concept of conservation can be brought to the fore through collective argument and decision making.

Special aspect of conservation education using latent process should be introduced into various age grade meetings and systems in the rural communities.

Adequate fines should be introduced for defaulters, especially in communities where they still practice traditional African religion.

Government and other conservation agencies should encourage communities still having and practicing traditional system of resources management, this can be done through positive motivation and incentives like prizes and award and also conservation tour or exhibition to such communities and encourage royalties and tariffs to be paid to such communities like the Ogolobi pond in Adihe, the Ungwa Ugbe Anibi etc.

Government should involve those practicing the traditional methods of managing natural resources into all conservation process since they are most endowed with traditional forest and natural resources management.

\section{References}

Appiah-Opoku, S. (2007). Indigenous beliefs and environmental stewardship: a rural Ghana experience. Journal of Cultural Geography, 22, 79-88. http://dx.doi.org/10.1080/08873630709478212

COPYRIGHT. (2008). JCG Press. This material is published under license from the publisher through the Gale Group, Farmington Hills, Michigan. All inquiries regarding rights or concerns about this content should be directed to Customer Support. (Hide copyright information)

Cox, P. A. (1995). Shaman as Scientist: Indigenous Knowledge Systems in Pharmacological Research and Conservation Biology. In, K Hostettmann, A Marston, M Maillard, and M Hamburger (eds.) Phytochemistry of Plants Used in Traditional Medicine. Clarendon Press, Oxford. pp. 1-15.

87.5450 .44

Deb, D., Deuti, K., \& Malhotra, K. C. (1997). Sacred grove relics as bird refugia. Current Science, 73, 815-817.

Deb, D., \& Malhotra, K. C. (2001). Conservation ethos in local traditions: the West Bengal heritage. Society and Natural Resources, 14, 711-724. http://dx.doi.org/10.1080/08941920152524909

Dorm-Adzobu, C., Ampadu-Agyei, O., \& Veit, P. G. (1991). Religious Beliefs and Environmental Protection: The Malshegu Sacred Grove in Northern Ghana. WRI Washington, DC, USA and Acts Press, Africa Centre for Technology Studies, Kenya.

Dwomoh, D. (1990). Forest Conservation: The contribution of sacred groves (A study of Sekyere West District, Ashanti Region). B.A (Hons) Dissertation, Geography Dept., Univ. of Ghana, Legon.

Eneji, C. V. O., Gubo, Q., Okpiliya, F. I., Aniah, E. J., Eni, D. D., \& Afanghideh, D. (2009a). Problems of Public Participation on Biodiversity Conservation: the Nigerian Scenario. Journal of Impact Assessment and Project Appraisal, Manchester UK, 27(4), 301-307. http://dx.doi.org/10.3152/146155109X479431

Eneji, C. V. O., Gubo, Q., Jian, X., Oden, S. N., \& Okpiliya, F. I. (2009b). A Review of the Dynamics of Forest Resources Valuation and Community Livelihood: Issues, Arguments and concerns. Journal of Agriculture, biotechnology and ecology, China, 2(2), 210-231.

Environmental Protection Council. (1976). Traditional Approaches to Conservation: Sacred Groves in Ghana. Mimeo. Report prepared for the Environmental Protection Council, Accra.

Falconer, J. (1992). People's uses and trade in nontimber forest products in Southern Ghana: A pilot study. ODA, Report.

Fargey, P. J. (1991). Assessment of the conservation status of the Boabeng Fiema Monkey Sanctuary. Report submitted to the Flora and Fauna Preservation Society. p.73.

Gyamfi-Fenteng, L. J, \& Abbiw, D. (1992). Management Strategy for Sacred Groves in Ghana Report prepared for the World Bank and the Environmental Protection Council.

Henshey, L . (2011). Religious \& Spiritual Mysteries Examiner. 
International Institute for Environment and Development. (1992). Environmental Synopsis of Ghana. Overseas Development Administration. p.28.

Johnson, N., Revenga, C., \& Echeverria, J. (2001). Managing water for people and nature. Science, 292, 1071-1072. http://dx.doi.org/10.1126/science.1058821

Kimmerer, R. W. (2002). Weaving traditional ecological knowledge into biological education: A call to action. BioScience, 52, 432-438. http://dx.doi.org/10.1641/0006-3568(2002)052[0432:WTEKIB]2.0.CO;2

McCammon, B. P. (2003). USDA- Forest Service, Pacific Northwest Region.

Mkenda, B. (2010). Environmental Conservation anchored in African cultural heritage, Ecology New People Magazine.

Paden, W. E. (2009). Religion. Redmond, WA: Microsoft Corporation.

Shastri, C. M., Bhat, D. M., Nagaraja, B. C., Murali, K. S., \& Ravindranath, N. H. (2002). Tree species diversity in a village ecosystem in Uttara Kannada district in Western Ghats, Karnataka. Current Science, 82, 1080-1084.

Silori, C. S., \& Badola, R. (2000). Medicinal plant cultivation and sustainable development -A case study in the buffer zone of the Nanda Devi Bioshere Reserve, Western Himalaya, India. Mountain Research and Development, 20, 272-279. http://dx.doi.org/10.1659/0276-4741(2000)020[0272:MPCASD]2.0.CO;2

Simberloff, D. S., \& Abele, L. G. (1976). Island biogeography theory and conservation practice. Science, 191, 285-286. http://dx.doi.org/10.1126/science.191.4224.285

Singh, J. S. (2002). The biodiversity crisis: a multifaceted review. Current Science, 82, 638-647.

Smith, E. A., \& Wishnie, M. (2000). Conservation and subsistence in small-scale societies. Annual Reviews Anthropology, 29, 493-524. http://dx.doi.org/10.1146/annurev.anthro.29.1.493

Snoo, G. D., \& Bertels, J. (2001). A Nobel Prize for sustainability, perhaps? Science, 294, 303. http://dx.doi.org/10.1126/science.294.5541.303b

Taylor, P. D. (2002). Fragmentation and cultural landscapes: tightening the relationship between human beings

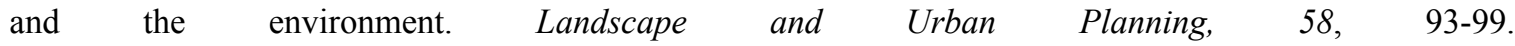
http://dx.doi.org/10.1016/S0169-2046(01)00212-2

Thompson, M., \& Homewood, K. (2002). Entrepreneurs, elites, and exclusion in Maasailand: Trends in wildlife conservation and pastoralist development. Human Ecology, 30, 107-138. http://dx.doi.org/10.1023/A:1014519113923

Tilman, D. (2000). Causes, consequences and ethics of biodiversity. Nature, 405, 208-211. http://dx.doi.org/10.1038/35012217

Tiwari, B. K., Barik, S. K., \& Tripathi, R. S. (1998). Biodiversity value, status, and strategies for conservation of sacred groves of Meghalaya, India. Ecosystem Health, 4, 20-32. http://dx.doi.org/10.1046/j.1526-0992.1998.00068.x

Tunon, H., \& Bruhn, J. G. (1994). Drugs in ancient texts. Nature, 369, 702. http://dx.doi.org/10.1038/369702a0

Tupper, M. (2002). Marine reserves and fisheries management. Science, 295, 1233. http://dx.doi.org/10.1126/science.295.5558.1233b

Udgaonkar, S. (2002). The recording of traditional knowledge: Will it prevent "bio-piracy?" Current Science, 82, 413-419.

Utkarsh, G., Gadgil, M., \& Rao, P. R. S. (1999). Intellectual property rights on biological resources: Benefiting from biodiversity and people's knowledge. Current Science, 77, 1418-1425.

Venkataraman, A. (2000). Incorporating traditional coexistence propensities into management of wildlife habitats in India. Current Science ,79, 1531-1535.

Wilson, E. O. (1998). Consilience: The Unity of Knowledge. The Future of Life. Knopf, New York. p. 254.

World Conservation Union. (1994). Guidelines for Protected Area Management Categories (IUCN, Gland, Switzerland, and Cambridge). 